\title{
Sedimentary evidence of soil organic matter input to the Curuai
}

\section{Amazonian floodplain}

\author{
Zocatelli, R. ${ }^{\mathrm{a}, \mathrm{b}, \mathrm{c}, \mathrm{d}^{*}}$, Moreira-Turcq, P. ${ }^{\mathrm{e}}$, Bernardes, M. ${ }^{\mathrm{d}}$, Turcq, B ${ }^{\mathrm{d}}$, Cordeiro, R.C. ${ }^{\mathrm{d}}$, Gogo, \\ $\mathrm{S}^{\mathrm{a}, \mathrm{b}, \mathrm{c}, \mathrm{f}}$, Disnar, J.R. ${ }^{\mathrm{a}, \mathrm{b}, \mathrm{c}}$, Boussafir, M. ${ }^{\mathrm{a}, \mathrm{b}, \mathrm{c}}$
}

${ }^{\mathrm{a}}$ Université d'Orléans, ISTO, UMR, 7327, 45071 Orléans, France

${ }^{\mathrm{b}}$ CNRS/INSU, ISTO, UMR 7327, 45071 Orléans, France

${ }^{\mathrm{c}}$ BRGM, ISTO, UMR 7327, BP 36009, 450600rléans, France

${ }^{\mathrm{d}}$ Universidade Federal Fluminense, Morro do Valonguinho s/n, Departamento de Geoquímica, Niterói, Rio de Janeiro, Brazil

${ }^{\mathrm{e}}$ IRD (Institut de Recherche pour le Développement). UR 234, GET, Centre IRD FranceNord, Bondy, France

${ }^{\mathrm{f}}$ Observatoire des Sciences de l'Univers en Région Centre, OSUC. 45071, Orléans, France

\begin{abstract}
A multi-proxy study has been performed on a sediment core from the Curuai floodplain, Central Amazonia. The combination of elemental, isotopic and molecular analysis of a $110 \mathrm{~cm}$ core (a record of ca. the last $100 \mathrm{yr}$ ) allowed reconstruction of the hydrological conditions of organic matter (OM) deposition. Two units could be delineated. The first (UI) was composed of three sub-units: UIa (0-15 $\mathrm{cm}$ ), composed of highly degraded organic particles originating from the surrounding soil and indicative of restricted transport; UIb $(15-48 \mathrm{~cm})$, during which the region was permanently flooded and the material stored came from soil runoff, mainly from alluvial forest; and UIc $(48-88 \mathrm{~cm})$ composed of material from Amazon River suspended sediment, itself originating from $\mathrm{OM}$ degradation in forest soil. In UII $(88-111 \mathrm{~cm})$, the OM originated mainly from the forest soil and other plant remains in the floodplain. The data reveal that, during the four distinct depositional periods, the sedimentary OM alternated between land derived soil and alluvial vegetation due to changes in hydrodynamics.
\end{abstract}

Keywords: Amazon Basin, carbon and nitrogen isotopes, lignin, Rock-Eval, organic petrography.

\section{Introduction}

Rivers ecosystems store, degrade and transport biogeochemical material of continental origin towards the sea. The majority of carbon does not reach the ocean. It is either transformed to $\mathrm{CO}_{2}$ and released to the atmosphere or stored within the floodplain as sedimentary organic carbon (OC) after erosion and transport from distant sites (Aufdenkampe et al., 2011). This lateral export of $\mathrm{C}$ from terrestrial ecosystems has been increasingly considered a mechanism for closing the terrestrial net ecosystem $\mathrm{C}$ balance. It is important to

\footnotetext{
*Corresponding author E-mail address: renata.zocatelli@cnrs-orleans.fr (R. Zocatelli).
} 
understand $\mathrm{C}$ flow in systems like the Amazon River because the net $\mathrm{C}$ balance for tropical land ecosystems remains one of the greatest uncertainties in the estimation of net $\mathrm{C}$ fluxes (Tian et al., 2000). The latest estimate doubled the global land area known to be seasonally permanently flooded $\left(20 \times 10^{6} \mathrm{~km}^{2}\right.$; Aufdenkampe et al., 2011 and references therein). The Amazon River drains a huge amount of organic matter (OM) that originates from the tropical forest in its basin. In fact, a large part of the $\mathrm{OC}$ exported to the Amazon mainstream originates from floodplains (or 'várzeas'; Moreira-Turcq et al., 2013). Floodplains act both as OM producers and as storage systems (Moreira-Turcq et al., 2004). In these floodplains the sediments are composed of material from the Amazon drainage basin (both terrestrial and aquatic), autochthonous material produced in the floodplain (phytoplankton) and material from the immediate surroundings (marginal input). The floodplains along the Amazon River have been studied to improve understanding of the Amazonian $\mathrm{C}$ cycle in the central Amazonia floodplains and to determine how $\mathrm{OM}$ is stored in the sediment. Lignin can be used to improve characterization of the sedimented OM. It is highly abundant and resistant to microbial degradation and is therefore considered to be an important component of the $\mathrm{C}$ cycle, particularly for $\mathrm{C}$ storage (Thevenot et al., 2010 and references therein). Due to its exclusively vascular plant origin, its abundance in the parent material and its resistance, this macromolecule has been used to infer the quantitative input and lateral transport of land plant C. However, only a few studies have examined its transport and sedimentation in the Amazon basin and floodplains (Hedges et al., 1986; Farella et al., 2001; Zocatelli et al., 2011).

The primary goals of the present work were to characterize the OM (source, origin and preservation) and study its sedimentation, using several organic proxies, in a $1 \mathrm{~m}$ core from the Curuai floodplain. It was estimated that the core represents $100 \mathrm{yr}$ of non-uniform sedimentation (Moreira-Turcq et al., 2004). 


\section{Material and methods}

\subsection{Study area and core sampling}

The Curuai floodplain lies between $1^{\circ} 50^{\prime} \mathrm{S}-02^{\circ} 15^{\prime} \mathrm{S}$ and $55^{\circ} 00^{\prime} \mathrm{W}-56^{\circ} 05^{\prime} \mathrm{W}$ on the southern margin of the Amazon River, $850 \mathrm{~km}$ from the mouth of the estuary (Fig. 1). It represents ca. $13 \%$ of the total flooded area of the Amazon River between Manaus and Óbidos (Maurice-Bourgoin et al., 2007) and is periodically or permanently connected to the main stream. The maximum floodable area, delineated by the boundary between "terra firme" forest (southwards, Fig. 1) and the Amazon, is $2430 \mathrm{~km}^{2}$, which corresponds to a water level in Curuai of ca. $11.5 \mathrm{~m}$. Terra firme forest is never flooded and is covered mainly by evergreen forest. During the low water season, the floodplain landscape consists mainly of grassland, low vegetation and alluvial forest. During periods of flooding, the alluvial forest can be fully covered, reaching the tree canopy and loosening the belt of aquatic grass along the lake margin (Richey et al., 2002). The yearly storage stage of the floodplain starts between November and January and lasts until May-June. The draining phase starts in July and lasts until November; the largest exported volume occurs from August until October (Bonnet et al., 2008).

\subsection{Core description}

TA11 core was collected from the northern part of the Curuai floodplain in Lake Santa Ninha (2³'11.86"S; 55²9'7.73"O, Fig. 1) using a $1.5 \mathrm{~m}$ PVC tube (10 cm diameter) during the low water period. In the laboratory, the core was opened, described and sub-sampled every $1 \mathrm{~cm}$ or $0.5 \mathrm{~cm}$, respecting the lithological units. Before slicing, an X-ray image (Table 1) of the core revealed sequential changes in sedimentation, and was highly laminated except at the surface. TA11 comprised two units: the basal unit (UII, 111-88 cm) and the upper unit (UI), composed of three sub-units. Sedimentation rate was calculated using ${ }^{210} \mathrm{~Pb}$ chronology 
(Moreira-Turcq et al. 2004) except for UII because the unsupported ${ }^{210} \mathrm{~Pb}$ concentration was near detection limit, precluding calculation of sedimentation rate. According to the chronology, the base of UI corresponds to an age of ca. 1900 AD.

\subsection{Bulk analysis}

Total OC (TOC) content (\%), N (\%) and C/N (g/g) were reported by Moreira-Turcq et al. (2004). Stable isotopic compositions $\left(\delta^{13} \mathrm{C}\right.$ and $\left.\delta^{15} \mathrm{~N}\right)$ were obtained using a Europe Hydra 20/20 mass spectrometer (Waterloo University, Canada and University of California, Davis, USA) with samples that had been decarbonated with 1.0 M HCl. The standard deviation was $0.06 \%$ and $0.13 \%$ for $\delta^{13} \mathrm{C}$ (Vienna Peedee Belemnite, VPDB) and $\delta^{15} \mathrm{~N}\left(15 \mathrm{~N}-\left(\mathrm{NH}_{4}\right)_{2} \mathrm{SO}_{4}\right.$, Sigma 29,928-6), respectively. Mass spectrometer precision was $+/-5 \%$.

Rock-Eval pyrolysis was carried out on $100 \mathrm{mg}$ powdered dry sediment with a "Turbo" Rock-Eval 6 pyrolyzer. The standard was $n^{\circ} 160.000$ (Vinci Technologies) and device precision was $+/-3 \%$. Details of the methodology of the temperature program have been described by Zocatelli et al. (2012a). Briefly, the program was: 2 min at $200{ }^{\circ} \mathrm{C}$, raised to 650 ${ }^{\circ} \mathrm{C}$ at $30{ }^{\circ} \mathrm{C} \cdot \mathrm{min}^{-1}$. The oxidation phase (an air stream) began with an isothermal stage at 400 ${ }^{\circ} \mathrm{C}$, then increased to $650{ }^{\circ} \mathrm{C}\left(30^{\circ} \mathrm{C} \cdot \mathrm{min}^{-1}\right)$ and was held for $5 \mathrm{~min}$ at this temperature. RockEval parameters were: (i) hydrogen index (HI, mg $\mathrm{HC} \mathrm{g}^{-1} \mathrm{TOC}$ ) and (ii) the oxygen index (OI, $\mathrm{mg} \mathrm{O}_{2} \mathrm{~g}^{-1}$ TOC).

Organic petrography extracts were prepared as described by Zocatelli et al. (2012b). Briefly, extracts were prepared from ca. $0.5 \mathrm{~g}$ sediment treated with $\mathrm{HCl}$ and $\mathrm{HF}$ to remove the mineral matrix. The first criterion for quantification was identification of recognizable biological structures. Phytoclast material was identified and grouped as follows: lignocellulose (LC), membranes and cuticles $(\mathrm{Mb}+\mathrm{Cut})$ and lignocellulose debris (Ld). Certain others particles assigned as algal OM, charcoal or amorphous OM (Gel AOM = 
gelified $\mathrm{AOM}$ and $\mathrm{Fl} \mathrm{AOM}=$ flocculated $\mathrm{AOM}) . \mathrm{Mb}+\mathrm{Cut}$ originated mainly from aquatic macrophytes whose tissue had settled in the water column and had become incorporated into the sediment (Turcq et al., 2002). Gel AOM derived from soil in the watershed (Tyson, 1995) and Fl AOM were identified as degraded material that had been altered in the aquatic environment. The Pearson product moment correlation was used to test for correlation with Statistica (Statsoft 2008). The level of significance for all of the tests was set at $p<0.05$.

\subsection{Lignin extraction and analysis}

Ca. $500 \mathrm{mg}$ sediment were oxidized with $\mathrm{CuO}: \mathrm{NaOH}$ in a $\mathrm{N}_{2}$ atmosphere $\left(3 \mathrm{~h}, 170{ }^{\circ} \mathrm{C}\right)$ in steel bombs following the method described by Hedges and Ertel (1982). Lignin phenols were separated using gas chromatography-mass spectrometry (GC-MS) with an HP 6890 gas chromatograph in splitless mode fitted with a DB-1 fused silica column (J\&W Scientific, DB$1,30 \mathrm{~m} \mathrm{x} 0.25 \mathrm{~mm}$ i.d., $0.25 \mu \mathrm{m}$ film) and quantified via flame ionization detection (FID). Assignment of the quantified peaks was confirmed by analyzing commercial standards with an HP 6890 mass selective detector. The total of the lignin-derived products $(\lambda)$ was quantified from vanillyl phenols (vanillin, acetovanillone, vanillic acid), syringyl phenols (syringealdehyde, acetosyringone, syringic acid) and cinnamyl phenols ( $p$-coumaric acid, ferulic acid). Ratio values of syringyl to vanillyl phenols $(\mathrm{S} / \mathrm{V}) \geq 0$ in complex environmental mixtures are generally indicative of the presence of at least some angiosperm tissue, whereas values of cinnamyl to vanillyl phenols $(\mathrm{C} / \mathrm{V}) \geq 0$ are indicative of the presence of non-woody material (Hedges and the Mann, 1979; Opsahl and Benner, 1995; Farella et al., 2001). Only a few organisms can perform lignin degradation. Acid to aldehyde ratio values of vanillyl moieties $[(\mathrm{Ad} / \mathrm{Al}) \mathrm{v}]>0.4$ are considered to correspond to an advanced state of degradation (Hedges et al., 1988a,b). Among additional $\mathrm{CuO}$ oxidation products, 3,5-dihydroxybenzoic acid (DHBA) was also quantified. It has been cited as a common product of fresh vascular 
plant macromolecules (e.g. tannins and other flavonoids; Louchouarn et al., 1999) in soils that accumulate during OM humification (Louchouarn et al., 1999; Farella et al., 2001). The analytical precision for both phenol yield and ratios was $\pm 5 \%$.

\section{Results}

\subsection{Bulk analysis}

According to previous work (Moreira-Turcq et al., 2004), and despite rather low TOC content (Fig 2a), complementary data such as stable isotopes and Rock-Eval analysis (Fig. $2 b, c)$ allowed us to distinguish two different units in the TA11 profile. Unit II (UII) was the deeper, extending from 110 to $88 \mathrm{~cm}$. Unit I was from $88 \mathrm{~cm}$ to the surface and was subdivided into three sub-units: sub-Unit Ia (UIa, 0 to $15 \mathrm{~cm}$ ), sub-Unit Ib (UIb, 15 to $44 \mathrm{~cm}$ ) and sub-Unit Ic (UIc, 44 to $88 \mathrm{~cm}$ ). The last differed from the other two by its nearly constant TOC content and regular, upward-increasing $\mathrm{C} / \mathrm{N}$ trend (Fig. 2a). In contrast, TOC and $\mathrm{C} / \mathrm{N}$ values were highly variable in UIa, UIb and UII. The $\delta^{13} \mathrm{C}$ values were highest in UIa and lowest in UIc $(-24.5 \pm 0.14 \%$ and $-26.5 \pm 0.67 \%$, respectively, Fig. $2 b)$. The $\delta^{15} \mathrm{~N}$ values varied between +2.1 and $+3.4 \%$ along the core. UIc had the highest values $(+3.1 \pm 0.16 \%$ o and UII the lowest $(+2.5 \pm 0.07 \%$, Fig. $2 b)$.

Along the entire core, $\mathrm{HI}$ values were low and variable (between 71 and $195 \mathrm{mg} \mathrm{CO}_{2} \cdot \mathrm{g}^{-}$ ${ }^{1}$ TOC, Fig. 2c). HI values were lowest in UIa ( $\left.85 \pm 6.7 \mathrm{mg} \mathrm{HC} \mathrm{g}^{-1} \mathrm{TOC}\right)$. HI increased in UIb and UIc, up to $112 \pm 10.6$ and $106 \pm 3.82 \mathrm{mg} \mathrm{HC} \mathrm{g}^{-1}$ TOC, respectively. In UII, HI varied from 97 to $195 \mathrm{mg} \mathrm{HC} \mathrm{g}^{-1}$ TOC. OI values varied from 514 to $127 \mathrm{mg} \mathrm{O}_{2} \mathrm{~g}^{-1}$ TOC all along the core (Fig. 2c); the highest values were in UIa, but there was a clearly marked decrease towards the base. OI values were low in UIb (175 $\pm 15 \mathrm{mg} \mathrm{O}_{2} \mathrm{~g}^{-1}$ TOC), increased in UIc (222 $\pm 18 \mathrm{mg} \mathrm{O}_{2} \mathrm{~g}^{-1}$ TOC) and decreased again in UII ( $\bar{x} 176 \pm 26 \mathrm{mg} \mathrm{O}_{2} \mathrm{~g}^{-1}$ TOC). 
Organic petrographic analysis of UIa showed differences in particle content and revealed that this sub-unit was non-uniform (Table 2). LC particles showed remarkable alteration, indicating strong oxidation in this section. In UIb, particles were particularly well preserved; Gel AOM and phytoclast material were dominant and phytoclast particles were coarse (LC $900 \mu \mathrm{m}$ and cuticle $1000 \mu \mathrm{m}$ ). Significant amounts of charcoal were also found (up to $22 \%$ of total particles at $31 \mathrm{~cm}$; Table 2). In UIc, all the phytoclasts were highly degraded. LC material covered ca. $72 \%$ of the particles, with an average size of $20 \mu \mathrm{m}$ per particle. $\mathrm{Mb}+\mathrm{Cut}$ had the lowest average of the entire core (ca. 20\%) and revealed high levels of cell wall degradation. On the whole, UII comprised the same proportion of phytoclasts as UIc. Unlike UIc, in UII, phytoclasts were relatively large $(1200 \mu \mathrm{m})$ and well preserved (Fig. 3b).

\subsection{Vertical distribution of $\mathrm{CuO}$ oxidation products}

The vertical distribution of $\lambda$ varied from 0.68 to $3.94 \mathrm{mg} 100 \mathrm{mg}^{-1}$ TOC. In UIb, it increased toward the base of the unit, reaching high values $\left(3.16 \mathrm{mg} 100 \mathrm{mg}^{-1}\right.$ TOC; Fig. $2 \mathrm{~d}$ and Table 2). The $\mathrm{S} / \mathrm{V}$ and $\mathrm{C} / \mathrm{V}$ ratios were highly variable throughout the core. S/V was always 2 to $5 \mathrm{x}$ higher than $\mathrm{C} / \mathrm{V}$, except at $90 \mathrm{~cm}$ where each index had the same value (1.59; Table 2). In UIa and UIb, the (Ad/Al)v index increased towards the top of the core (from 0.05 to 0.58$)$. In UIc and UII, the $(\mathrm{Ad} / \mathrm{Al}) \mathrm{V}$ ratio was $0.49 \pm 0.09$ and $0.24 \pm 0.06$, respectively (Fig. 2e). For DHBA/V, two trends were observed: a decrease from the bottom of the core to the top of UIc and then an increase from the top of UIa. Higher DHBA/V values were found in UII $(0.40 \pm 0.15)$.

\section{Discussion}

\subsection{Source and preservation of OM in Curuai floodplain sediments}

Organic petrographic analysis revealed that the TOC peaks in UIb and UII were principally caused by large and well-preserved plant remains. In UIa, the high content of 
oxidized Gel AOM indicated more degraded material. Pseudo-van Krevelen diagrams are used to indicate pools of samples with a similar OM composition, Type I represent algal OM, Type II lacustrine OM and Type III terrestrial OM. Here, when plotted on a pseudo-van Krevelen diagram, all the samples from UIb, UIc and UII clustered in the same field; however, there was a slight trend between Type II and Type III OM (UIb $\rightarrow$ UII $\rightarrow$ UIc $\rightarrow$ UIa). The trend (Fig. 3) was interpreted as a degradation gradient that could be clearly seen for the UIa samples, especially those from the upper $10 \mathrm{~cm}$ of the core that exhibited high OI values, indicative of extensive oxidation (Tyson, 1995; Disnar et al., 2003). This interpretation is supported by Moreira-Turcq et al. (2004), who described the core location as being not permanently flooded, favoring extensive OM mineralization in the top few $\mathrm{cm}$.

$\delta^{13} \mathrm{C}, \delta^{15} \mathrm{~N}$ values and $\mathrm{C} / \mathrm{N}$ ratio are classically used to assess $\mathrm{OM}$ source, generally terrestrial vs. aquatic (e.g. Meyers, 1997, 2003; Lamb et al., 2006). Data from TA11, as well as previous data from Curuai surface sediments, Curuai surrounding vegetation (Amorim et al., 2010; Zocatelli et al., 2011, respectively) and soil OM in Santarém, were plotted in a $\delta^{13} \mathrm{C}$ vs. C/N diagram (Fig. 4a). All the TA11 data points clustered in the soil-derived OM field. UIb was shifted towards the soil derived and $\mathrm{C}_{3}$ plant fields close to the Santarem soil OM, while data from the UIc samples fell within the particulate OC (POC) field, close to the values for Curuai floodplain surface sediments sampled during high water (Amorim et al., 2010) and those measured for the Amazon River (Hedges et al., 1986). Suspended matter from the Amazon River is interpreted as being related to soil OM adsorbed onto fine mineral particles and transported by the river (Hedges et al., 1986). The results indicate that UIc represents floodplain conditions in high water with an effective connection to the mainstream. In a $\delta^{13} \mathrm{C}$ vs. $\delta^{15} \mathrm{~N}$ diagram (Fig. $4 \mathrm{~b}$ ) the TA11 data points clustered close to Eel River in the lacustrine field and were surrounded by Curuai floodplain surface sediments (Amorim et al., 2006). UIc 
samples were shifted from $\mathrm{C}_{3}$ Curuai plants, whereas UIa and UIb were slightly shifted from $\mathrm{C}_{4}$ Curuai plants. The highest $\delta^{15} \mathrm{~N}$ values were found in UIc and were interpreted as indicating an Amazon River influence. Unlike TA11 sediments that showed low $\delta^{15} \mathrm{~N}$ values, Santarém Amazon forest soils were ${ }^{15} \mathrm{~N}$ enriched (black squares, ca. $+8 \%$; Ometto et al., 2006; Martinelli et al., 1999; Nardoto et al., 2008) as well as POC material in the Amazon River $(+5.3 \pm 0.4 \%$ o $\mathrm{n}=36$; Martinelli et al., 1992). TA11 sediments were contained in a lower buffer range of values (between 2.1 and 3.4\%o), probably linked to environmental changes, that could affect deposition conditions and partially a change the the proportions of sources, i.e. algal vs. land plant contributions.

In UIc, an increase in mineral remains in petrographic lamina after acid treatment and the Fl AOM (\%; Fig. 3b) showed a phase strongly influenced by clay and silt from the Amazon River. The correlation between FlAOM and $\delta^{13} \mathrm{C}$ values $(\mathrm{R} 0.81, \mathrm{n}=12, \mathrm{p}=0.007)$ indicated that sediment richer in FI AOM had more negative $\delta^{13} \mathrm{C}$ values (ca. $-27.5 \%$ ) identical to the Amazon River OM. In contrast, $\delta^{13} \mathrm{C}$ values in UII were strongly anti-correlated with phytoclast content $(\mathrm{R} 0.97, \mathrm{n}=4, \mathrm{p}=0.031)$. These phytoclasts are well-preserved particles derived from aquatic macrophytes and alluvial forest vegetation.

\subsection{Terrigenous origin of OM in recent floodplain lakes}

The distribution and yield of lignin-derived $\mathrm{CuO}$ oxidation products provided additional information on the stored terrestrial OM. Lignin content of the was consistent with the content of coastal and lacustrine settings (Hu et al., 1999), as well as riverine sediments (Tapajós River, an Amazon tributary downstream of the Curuai floodplain; Farella et al., 2001). In agreement with the discussion in Section 4.1, the highest $\lambda$ content in UIb corroborated with a significant input of preserved phytoclasts to the sediments. UIc showed the lowest $\lambda$ content, fully consistent with a high proportion of highly degraded and small-sized phytoclasts. 
Cut $+\mathrm{Mb}$ particles had orange-brown areas within the cell outlines, also indicating strong degradation (Tyson, 1995). These data all suggest extensive OM degradation, with the resulting loss of macromolecular compounds, such as lignin.

A classical S/V vs. C/V diagram was used to obtain further information on the origin of the lignin (e.g. Hedges and Mann, 1979; Hedges et al., 1986; Louchoarn et al., 1997; Dittmar and Lara, 2001; Tareq et al., 2004). Hedges et al. (1986) delineated areas corresponding to fresh plant material (leaves and wood) from the Amazonian basin. Zocatelli et al. (2011) showed that macrophytes and Poaceae surrounding the Curuai floodplain provided similar ratio values to those obtained by Hedges et al. (1986) for the Amazonian basin (Fig. 5). A subset of the TA11 core sediment samples, which clustered in the grass and angiosperm leaf field and were mainly from UIa and parts of UIb and UII, indicated a contribution from nonwoody tissue. This contribution could have been provided by the understory vegetation of the nearby forest and/or by aquatic vegetation in the surrounding floodplain. Two cores from the Piranga and Cametá stations along the Tapajós River, analyzed by Farella et al. (2001), are also shown in Fig. 5. They produced lower S/V and C/V values than TA11 sediment samples. Coarse and fine suspended particulate matter (CSPM and FSPM, respectively) taken from the same location (Farella et al., 2001) displayed values just slightly lower than those from the TA11 samples. The results for CSPM samples from the Amazon River upstream of Curuai (Hedges et al., 1986) gave values that were closer to those of the TA11 core than to those of Farella et al. (2001). This result suggests that river OM integrates several types of lignocellulose sources and that TA11 sediments were very similar to those transported by the modern Amazon River. Certain samples from UIb, UIc and UII had intermediate S/V and C/V ratios, suggesting that they inherited their lignin content from a combination of terrestrial sources. However, these data should be considered with caution because an S/V vs. C/V 
diagram is limited by the structural changes that $\mathrm{OM}$ experiences during degradation (Thevenot et al., 2010). UIc OM sediment yielded high (Ad/Al)v values, indicating advanced degradation. Similarly, higher DHBA/V values corroborate the hypothesis that the lignocellulose material is derived from erosion of forest soil in the Amazon basin. Farella et al. (2001) found lower DHBA/V values than those in the TA11 core, namely, between 0.20 and 0.05 (top to bottom core of the Tapajós River core, respectively). These authors interpreted the values as resulting from deforestation in the Tapajós catchment. In Sepetiba Bay, a highly agricultural region in southeastern Brazil, Rezende et al. (2010) found DHBA/V values that were $10 \mathrm{x}$ higher than those in the Curuai floodplain due to extensive soil erosion promoted by agricultural practices. Our data are thus in the range of published data that indicate extensive erosion of forest soils. This process provides OM to the Curuai floodplain that was degraded during pedogenetic formation in the soils and/or during transport by the river.

\subsection{Reconstruction of hydrological conditions during OM deposition}

Water input to the Curuai floodplain is dominated year round by Amazon input, accounting for ca. 77\% of the total annual input (Bonnet et al., 2008). This influence is important at the TA11 sampling location because of its proximity to one of the principal channels connecting the river and the floodplain (ca. $3.5 \mathrm{~km}$ ). The Curuai water level is very close to the river water level, and the annual fluctuations are nearly synchronous (MoreiraTurcq et al., 2013). UIa is composed mainly of pedogenetic OM with high degree of degradation and large organic particles. This could be explained by the presence of marginal macrophyte vegetation in this shallow area during the low water period when the inlet channel withdraws. In this unit, OM mineralization might be linked to oxidation when the sediment is no longer covered by water during the low water period. 
Compared with UIa, UIb had a higher TOC content and contained better-preserved material. This might indicate that the core sampling location was more flooded and that some of the material came from the alluvial forest. High lignin content and the presence of large phytoclast particles with sharp boundaries and intact internal structures indicate little transport, consistent with an alluvial forest origin. The laminated fine sand and silt of this unit were most likely deposited near the channel outlet. This sediment coarsens upward, corresponding to progradation of the channel into the lake.

UIc differed drastically from the two overlying layers (and from UII) because of its uniformly low TOC content. This and the high degree of OM degradation (as evidenced by multiple parameters) are strikingly similar to Amazon suspended sediment. The relatively higher amounts of clay and silt indicate weaker hydrodynamics than recorded in other units and the high Amazon River influence. Differences between units are linked to the channel inlet located further from the sampling site at the former time than at present. Thus, the recent silting of the lake began with fine deposits from Amazon River suspended sediment (UIc); then, for UIb, deepening and channel progradation allowed the introduction of coarser sediment from the erosion of alluvial banks.

In UII, the OM composition was variable, with certain samples containing a significant proportion of OM derived from the forest soils and other plant remains from the surrounding Curuai floodplain. All the samples from this unit showed relatively good OM preservation. The OM composition and abundance in UII were sometimes similar to UIb and occasionally to UIc. Information on the OM, coupled with the laminated sediment core, indicates events with greater and lesser influence of the Amazon River on the floodplain. In periods of strong influence, the OM stock derived from watershed "terra firme" forest soil. In periods of low influence, the OM deposited in the floodplain ecosystem shows characteristics of a closed 
environment in which aquatic plants grew on the shallow flooded regions and the surrounding floodplains.

\section{Conclusions}

This work provides new information regarding the past $100 \mathrm{yr}$ of interaction between the Curuai floodplain and the Amazon River, as observed in fluctuation in sedimentation and documented by analysis of the organic content of lacustrine sediment in the TA11 core. The study of the bulk and molecular sedimentary OM allows characterization of organic components originating from: (i) autochthonous production, (ii) aquatic plants, (iii) the Amazon River and (iv) soil runoff. Based on comparison with surface sediments, the TA11 core represents floodplain conditions with an effective connection to the main stream of the Curuai floodplain. The OM preservation varied within the core and the OM characteristics were tightly linked to hydrodynamic variation. UIa was marked by a long duration of seasonal subaerial exposures in a shallow area during low water periods when the main channel withdrew and favored OM mineralization. In UIb, the study area was more flooded and the OM came from the alluvial forest. Coarsening upward sediments correspond to channel progradation into the lake, with the erosion of alluvial banks providing alluvial forest OM. UIc differed from the other units, showing similarities with Amazon River suspended sediment, indicating less intense channel erosion, a result that is consistent with its finer granulometry. The recent silting of the lake began with fine deposits from Amazon River suspended sediment (UIc) then, for UIb, the deepening and progradation of the channel introduced coarser sediment from erosion of alluvial banks.

In Unit II, regardless of its variable composition, the OM was well-preserved. The intensity of the water supply determines the amount and source of OM deposited in Curuai floodplain. This unit exhibits characteristics of both a closed environment in which aquatic 
plants grew on shallow flooded areas and the Amazon River. This study suggests that significant amounts of $\mathrm{OM}$ are accumulated in Curuai Floodplain, which evidences the role of

floodplains in Amazonian carbon storage.

\section{Acknowledgments}

The study was accomplished as part of a collaborative project between the IRD-France, CNPq-Brasil and ISTO/CNRS. Varzea de Curuai is being studied within the framework of the HYBAM network. The research was also supported by a CNRS/INSU/PALEO2 - PASCAL project (PASt climate change impacts on Carbon Accumulation in Amazonia floodplain Lakes). One of us (R.Z.) received financial support from the CNPq and CAPES. We acknowledge support from ANR 2010 BLANC 608 01 ELPASO. We thank M. Hatton and R. Boscardin for assistance during different phases of the study. The authors would also like to thank two anonymous reviewers for constructive comments.

Associate Editor - P. A. Meyers

\section{References}

Amorim, M.A., Moreira-Turcq, P.F., Turcq, B.J., Cordeiro, R.C, 2010. Origem e dinâmica da deposição dos sedimentos superficiais na Várzea do Lago Grande de Curuái, Pará, Brasil. Acta Amazonica 39, $155-162$.

Amorim, M.A., 2006. Estudo da Sedimentação Recente na Várzea do Lago Grande de Curuai, Pará, Brasil. MSc dissertation, Universidade Federal Fluminense, Niterói, RJ, 144 pp.

Aufdenkampe, A.K. Mayorga, E., Raymond, P.A., Melack, J.M., Doney, S.C., Alin, S.R., Aalto, R.E., Yoo, K., 2011. Riverine coupling of biogeochemical cycles between land, oceans, and atmosphere. Frontiers in Ecology and the Environment 9, 53-60.

Bonnet, M.P., Barroux, G., Martinez, J.M., Seyler, F., Moreira-Turcq, P., Cochonneau, G., Melack, J.M., Boaventura, G., Maurice-Bourgoin, L., León, J.G., Roux, E., Calmant, S., Kosuth, P., Guyot, J.L., Seyler, P., 2008. Floodplain hydrology in an Amazonian floodplain lake (Lago Grande de Curuai). Journal of Hydrology 349, 18-30.

Disnar, J.R., Guillet, B., Keravis, D., Di-Giovanni, Sebag, D., 2003. Soil organic matter (SOM) characterization by Rock-Eval pyrolysis: scope and limitations. Organic Geochemistry 34, 327-343.

Dittmar, T., Lara, R.J., 2001. Molecular evidence for lignin degradation in sulfate reducing mangrove sediments (Amazônia, Brazil). Geochimica et Cosmochimica Acta 65, 1403-1414.

Farella, N., Lucotte, M., Louchouarn, P., Roulet, M., 2001. Deforestation modifying terrestrial organic transport in the Rio Tapajós, Brazilian Amazon. Organic Geochemistry 32, 1443-1458.

Hamilton, S.K., Lewis, JR., 1992. Stable carbon and nitrogen isotopes in algae and detritus from Orinoco River floodplain, Venezuela. Geochimica Cosmochimica Acta 56, 4237-4246.

Hedges, J.I., Mann, D.C., 1979. The characterization of plant tissues by their lignin oxidation products. Geochimica et Cosmochimica Acta 43, 1803-1807.

Hedges, J.I., Ertel, J.R., 1982. Characterization of lignin by gas chromatography of cupric oxide oxidation products. Analytical Chemistry 54, 174-178.

Hedges, J.I., Clark, W.A., Quay, P.D., Richey, J.E., Devol, A.H., Santos, U.M., 1986. Composition and fluxes of particulate organic material in the Amazon River. Limnology and Oceanography 31, 717-738.

Hedges, J.I., Blanchette, R.A., Weliky, K., Devol, A.H., 1988a. Effects of fungal degradation on the CuO oxidation products of lignin: a controlled laboratory study. Geochimica et Cosmochimica Acta 52, 2717 2726.

Hedges, J.I., Clark, W.A., Cowie, G. L., 1988b. Organic matter sources to the column and surfaicial sediments of a marine bay. Limnology and Oceanography 33, 1116-1136.

Hu, F.S., Hedges, J.I., Gordon, E.S., Brubaker, L.B., 1999. Lignin biomarkers and pollen in postglacial sediments of an Alaskan lake. Geochimica et Cosmochimica Acta 63, 1421-1430.

Lamb, A.L., Wilson, G.P., Leng, M.J., 2006. A review of coastal palaeoclimate and relative sea-level reconstructions using $\delta^{13} \mathrm{C}$ and $\mathrm{C} / \mathrm{N}$ ratios in organic material. Earth-Science Reviews 75, 29-57.

Louchouarn, P., Lucotte, M., Farella, N., 1999. Historical and geographical variations of sources and transport of terrigenous organic matter within a large-scale coastal environment. Organic Geochemistry 30, 675-699. 
Martinelli, L.A., Victoria, R.L., Trivelin, P.C.O., Devol, A.H., Richey, J.E., $1992 .{ }^{15} \mathrm{~N}$ natural abundance in plants of the Amazon River floodplain and potential atmospheric $\mathrm{N}_{2}$ fixation. Oecologia 90, 591-596.

Martinelli L.A., Piccolo M.C., Townsend A.R., Vitousek, P.M., Cuevas, E., Mcdowell, W., Robertson, G.P., Santos, O.C., Treseder K., 1999. Nitrogen stable isotopic composition of leaves and soil: tropical versus temperate forests. Biogeochemistry 46, 45-65.

Martinelli, L.A., Victoria, R.L., de Camargo, P.B., Piccolo, M.D., Mertes, L., Richey, J.E., Devol, A.H., Forsberg, B.R., 2003. Inland variability of carbon-nitrogen concentrations and $\delta^{13} \mathrm{C}$ in Amazon floodplain (varzea) vegetation and sediment. Hydrological Processes 17, 1419-1430.

Martinez, J.M., Le Toan, T., 2007. Mapping of flood dynamics and vegetation spatial distribution in the Amazon flooplain using multitemporal SAR data. Remote Sensing Environment 108, 209-233.

Maurice-Bourgoin, L., Bonnet, M.-P., Martinez, J.M., Kosuth, P., Cochonneau, G., Moreira-Turcq, P., Guyot, J.L., Vauchel, P., Filizola, N., Seyler, P., 2007. Temporal dynamics of water and sediment exchanges between the Curuai floodplain and the Amazon River, Brazil. Journal of Hydrology 335, 140-156.

Melack, J.M., Forsberg, B., 2001. Biogeochemistry of Amazon floodplain lakes and associated wetlands. In: McClain, M.E., Victoria, R. L., Richey, J.E. (Eds), The Biogeochemistry of the Amazon Basin and its Role in a Changing World. Oxford University Press, Oxford, pp. 235-276.

Meyers, P.A., 2003. Applications of organic geochemistry to paleolimnological reconstructions: a summary of examples from the Laurentian Great Lakes. Organic Geochemistry 34, 261-289.

Meyers, P.A., 1997. Organic geochemical proxies of paleoceanographic, paleolimnologic, and paleoclimatic processes. Organic Geochemistry 27, 213-250.

Moreira-Turcq, P., Jouanneau, J. M., Turcq, B., Seyler, P., Weber, O., Guyot, J. L., 2004. Carbon sedimentation at Lago Grande de Curuai, a floodplain Lake in the low Amazon Region: insights into sedimentation rates. Palaeogeography, Palaeoclimatology, Palaeoecology 214, 27-40.

Moreira-Turcq, P., Amorim, M., Bernardes, M., Bonnet, M.-P., Maurice, L., Perez, M., Seyler, P. 2013. Seasonal variability in concentration, composition, age and fluxes of particulate organic carbon exchanged between the floodplain and Amazon River. Global Biogeochemical Cycles 27, 1-12.

Nardoto, G.B., Ometto, J.P.H.B., Ehleringer, J.R., Higuchi, N., Bustamante, M.M.C., Martinelli, L.A., 2008. Understanding the influences of spatial patterns on $\mathrm{N}$ availability within the Brazilian Amazon Forest. Ecosystems 11, 1234-1246.

Ometto, J.P.H.B., Ehleringer, J.R., Domingues, T.F., Berry, J.A., Ishida, F.Y., Mazzi, E., Higuchi, N., Flanagan, L.B., Nardoto, G.B., Martinelli, L.A., 2006. The stable carbon and nitrogen isotopic composition of vegetation in tropical forests of the Amazon region, Brazil. Biogeochemistry 79, 251-274.

Peters, K.E., Sweeney, R.E., Kaplan, I.R., 1978. Correlation of carbon and nitrogen stable isotope ratios in sedimentary organic matter. Limnology and Oceanography 23, 598-604.

Peterson, B.J., Howarth, R.W., 1987. Sulfur, carbon, and nitrogen isotopes used to trace organic matter flow in the salt-marsh estuaries of Sapelo Island, Georgia. Limnology and Oceanography 32, 1195-1213.

Rezende, C.E., Pfeiffer, W.C., Martinelli, L.A., Tsamakis E., Hedges, J.I., Keil, R.G., 2010. Lignin phenols used to infer organic matter sources to Sepetiba Bay, RJ, Brasil. Estuarine, Coastal and Shelf Science 87, 479486.

Richey, J.E., Melack, J.M., Aufdenkampe, A.K., Ballester, V.M., Hess, L.L., 2002. Outgassing from Amazonian rivers and wetlands as a large tropical source of atmospheric $\mathrm{CO}_{2}$. Nature 4166, 617-620.

Tareq, S.M., Tanaka, N., Ohta, K., 2004. Biomarker signature in tropical wetland: lignin phenol vegetation index (LPVI) and its implications for reconstructing the paleoenvironment. Science of the Total Environment 324, 91-103.

Thevenot, M., Dignac, M-F., Rumpel, C., 2010. Fate of lignins in soils: A review. Soil Biology \& Biochemistry 42, 1200-1211.

Tian, H., Melillo, J.M., Kicklighter, D.W., McGuire, A.D., Helfrich, J., Moore, B., Vörösmarty, C.J., 2000. Climatic and biotic controls on annual carbon storage in Amazonian ecosystems, Global Ecology \& Biogeography 9, 315-335.

Turcq, B., Albuquerque, A.L.S., Cordeiro, R.C., Sifeddine, A., Simões Filho, F., F.L.A., Souza, G., Abrão, J.J., Oliveira, F.B.L., Silva, A.O., Capitâneo, J.A., 2002. Accumulation of organic carbon in five Brazilian lakes during the Holocene. Sedimentary Geology 148, 319-342.

Tyson, R.V., 1995. Sedimentary Organic Matter: Organic Facies and Palynofacies Analysis. Chapman \& Hall, London, $615 \mathrm{pp}$.

Zocatelli, R., Cecanho, F., Amorim, M., Bernardes, M., Moreira-Turcq, P., Turcq, B., Sifeddine, A., Cordeiro, R.C, 2011. Uso dos fenóis da lignina no estudo da matéria orgânica na Várzea do Lago Grande Curuai, Pará e no Lago do Caçó, Maranhão, Brasil. Acta Amazonica 41, 195-204. 
Zocatelli, R., Lavrieux, M., Disnar, J.R., Le Milbeau, C., Jacob, J., Bréheret, J.G., 2012a. Free fatty acids in Lake Aydat catchment soils (French Massif Central): sources, distributions and potential use as sediment biomarkers. Journal of Soils and Sediments 12, 734-748.

Zocatelli, R., Turcq, B., Boussafir, M., Cordeiro, R.C., Disnar, J.R., Costa, R.L., Sifeddine, A., Albuquerque, A.L.S., Bernardes, M.C., Jacob, J., 2012b. Late Holocene paleoenvironmental changes in Northeast Brazil recorded by organic matter in lacustrine sediments of Lake Boqueirão. Palaeogeography, Palaeoclimatology, Palaeoecology 363-364, 127-134.

\section{TABLE CAPTIONS}

\section{Table 1}

Lithological description, sedimentation rate and grain size fractions of the TA11 core (after Moreira-Turcq et al., 2004; n.c., not calculated).

\section{Table 2}

OM parameters from TA11 sediments. Lignin data: total lignin-derived products $(\lambda=$ vanillyl + syringyl + cinnamyl phenols), ratio values of syringyl to vanillyl phenols (S/V) and cinnamyl to vanillyl phenols $(\mathrm{C} / \mathrm{V})$, acid to aldehyde ratio values [(Ad/Al)v], 3,5dihydroxybenzoic acid to vanillyl phenols (DHBA/V). Organic petrography data: relative contents of groups of gelified and flocculated amorphous organic matter (Gel AOM and Fl AOM, respectively), algal OM, lignocellulose particles (LC), membranes and cuticles particles $(\mathrm{Mb}+\mathrm{Cut})$, lignocellulose debris particles $(\mathrm{Ld})$ and charcoal particles.

\section{FIGURE CAPTIONS}

Fig. 1. Location of Curuai Floodplain and TA11 core (white diamond). Numbers represent interconnected lakes: Lake Santa Ninha (1); Lake Poção (2) and Lake Grande (3).

Fig. 2. Downcore variation of Curuai Floodplain core (TA11): (a) TOC and C/N (in wt. - g/g; as previously shown by Moreira-Turcq et al., 2004) compared with (b) isotopic contents $\left(\delta^{13} \mathrm{C}\right.$ and $\left.\delta^{15} \mathrm{~N}\right)$, to (c) oxygen index $(\mathrm{OI})$ and hydrogen index $(\mathrm{HI})$ delivered from Rock-Eval pyrolysis, (d) total lignin content $(\lambda)$, (e) $(\mathrm{Ad} / \mathrm{Al}) \mathrm{v}$ and DHBA/V ratios and $\mathrm{x}$-ray core image.

Fig. 3. Pseudo Van Krevelen diagram for OM sediments from Lake Santa Ninha (a), appearance and proportion of organic constituents in the organic petrography (b).

Fig. 4. (a) $\delta^{13} \mathrm{C}$ vs. $\mathrm{C} / \mathrm{N}$ ratio diagram adapted from Lamb et al. (2006). Curuai superficial sediments (+; Amorim et al., 2009), $\mathrm{C}_{3} / \mathrm{C}_{4}$ surrounding vegetation (asterisks; Zocatelli et al., 2011) and soil OM in Santarém (black squares; Ometto et al., 2006) are also plotted. (b) $\delta^{15} \mathrm{~N}$ vs. $\delta^{13} \mathrm{C}$ diagram adapted from Meyers et al. (1997), originally noted by Peters et al. (1978). Additional data: $\mathrm{C}_{3}$ land plant and marine plankton end members (Peterson and Howarth, 1987), Curuai superficial sediments by Amorim et al., (2009), Santarém soil OM (black squares; Ometto et al., 2006) and Amazonian POC (Martinelli et al., 1992, 2003). C/N content is in wt. - $\mathrm{g} / \mathrm{g}$; as previously shown by Moreira-Turcq et al., 2004).

Fig. 5. S/V vs. C/V ratio for TA11 sediment profile. Adapted from Hedges et al. (1986). Additional data: Curuai superficial sediment samples (+), $\mathrm{C}_{3} / \mathrm{C}_{4}$ surrounding vegetation (asterisks; Zocatelli et al., 2011) and core sediments from the Tapajós River watershed (gray zone; Farella et al., 2001). 
Fig. 1

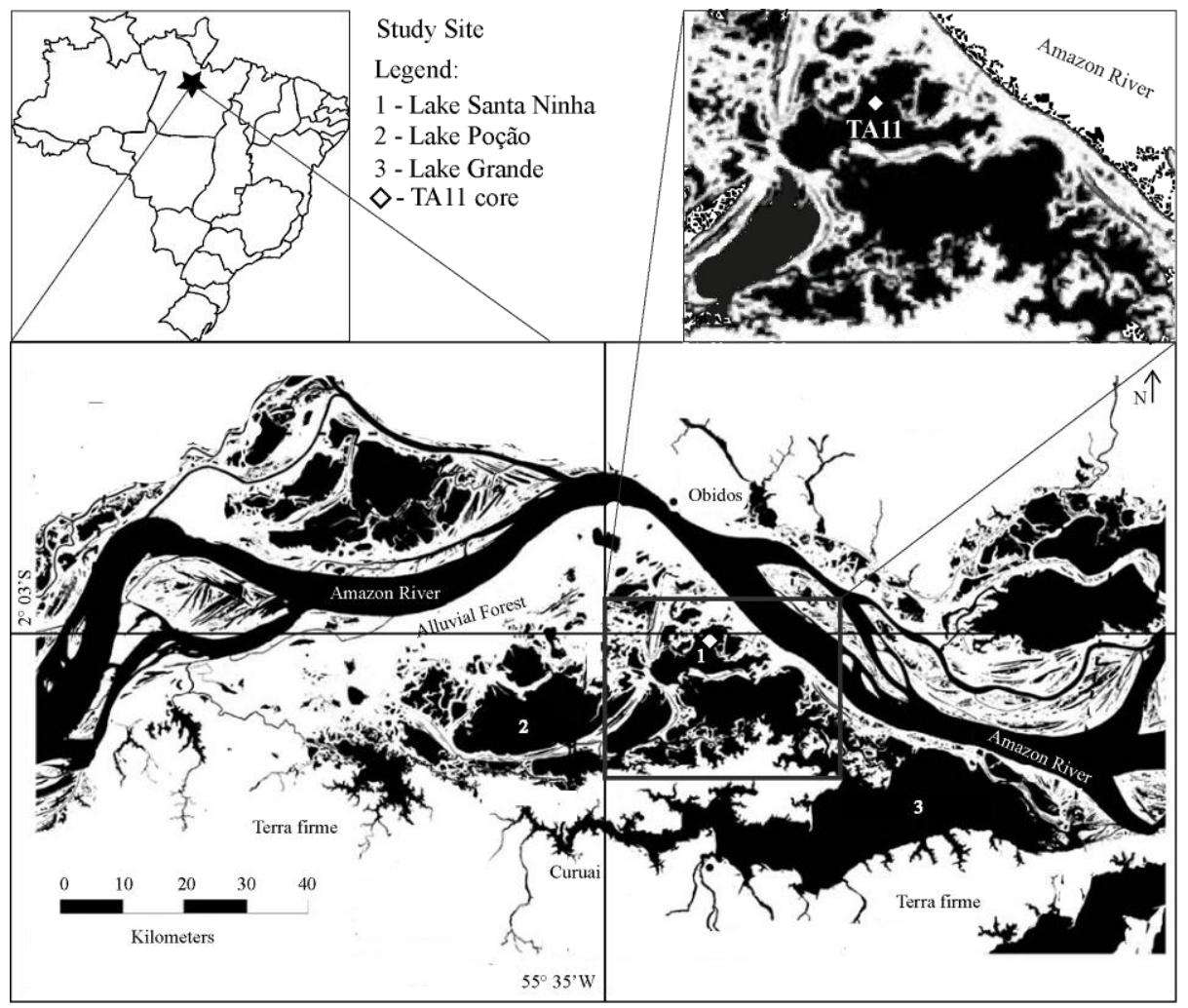


Fig. 2

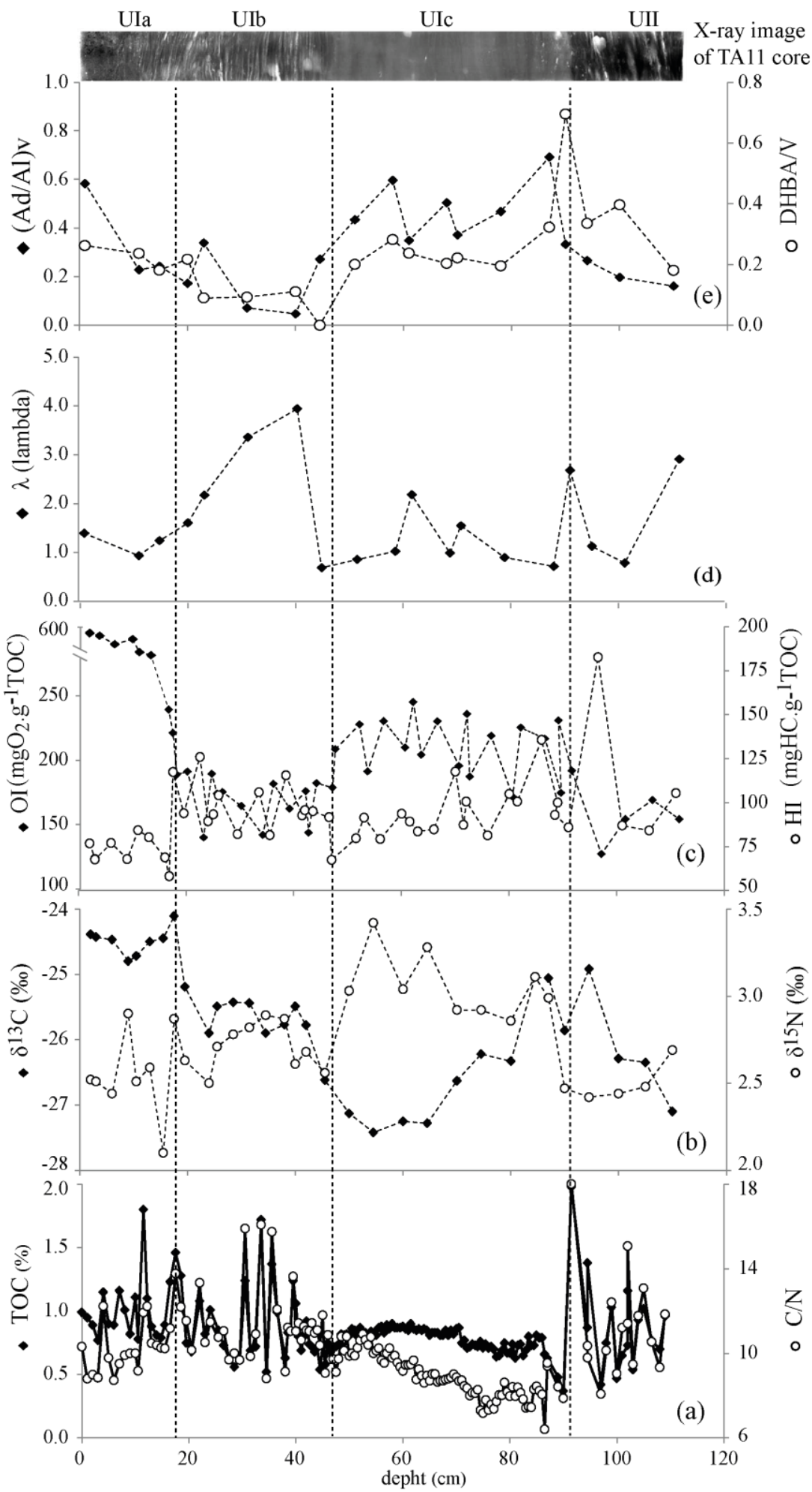


Fig. 3
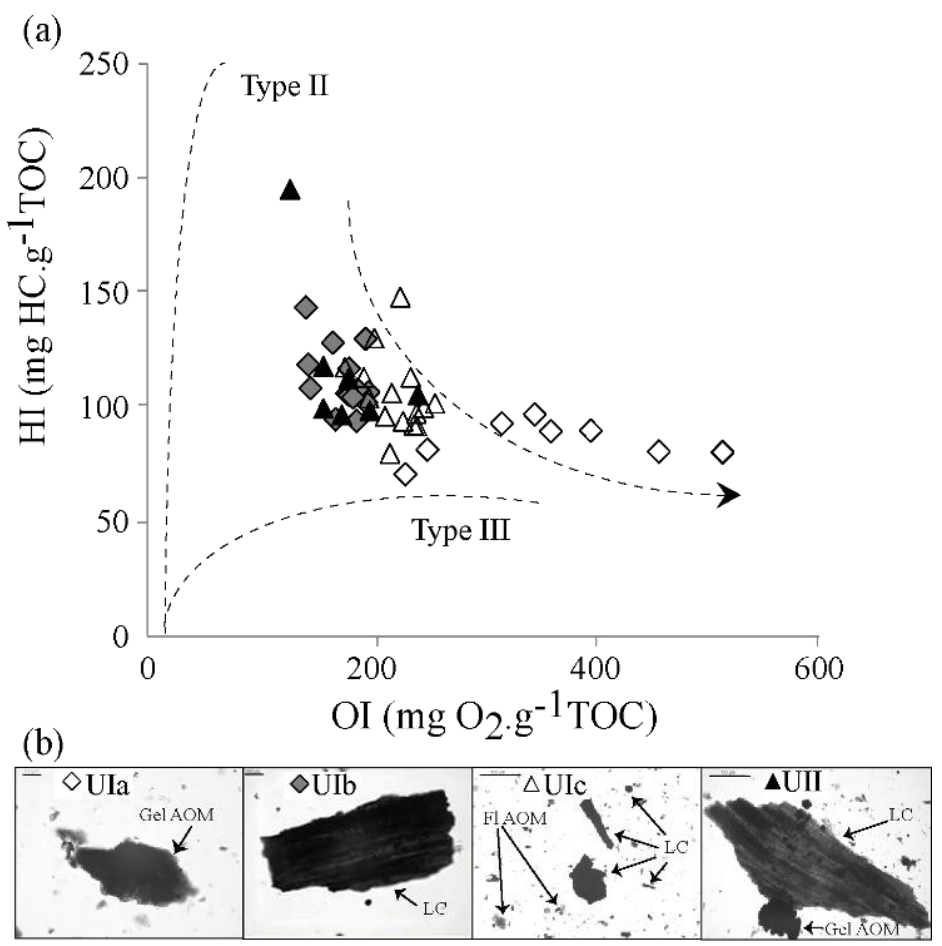

Fig. 4
Legend:
$\diamond \mathrm{UIa}$
$\diamond \mathrm{UTb}$
$\triangle \mathrm{UIc}$
$\Delta$ UII
* - C3 Curuai Plants
*-C4 Curuai Plants
- Santarém soil organic matter
1 - Estuarine C3 Land Plants

3 - Black sea

4 - California Rivers

6 - Santa Barbara Basin

5 - Gulf of Alaska

7 - Marine Phytoplancton
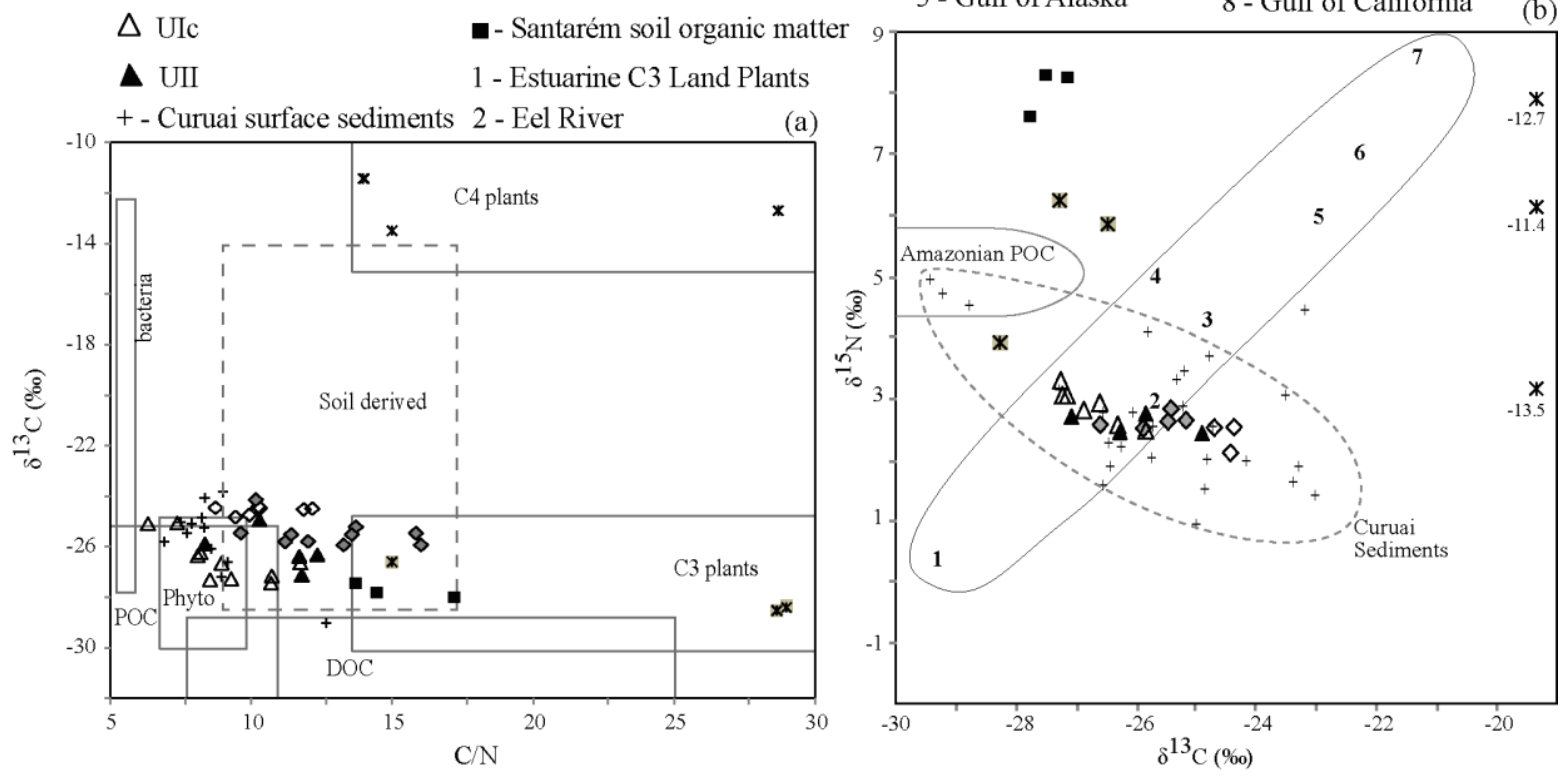
Fig. 5

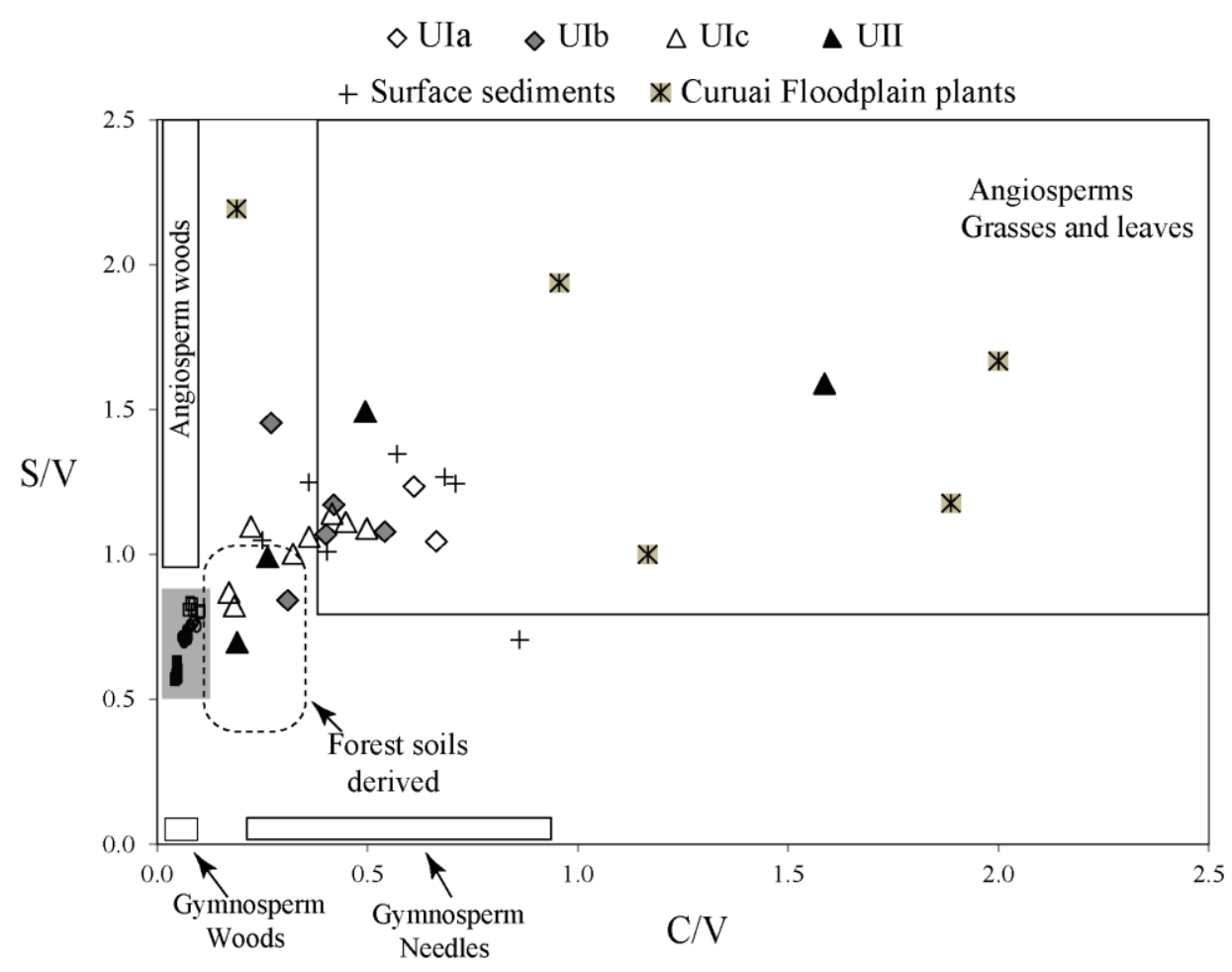

Table 1

\begin{tabular}{ccccccc}
\hline Depht. (cm) & Lithology & $\begin{array}{c}\text { Sedimentation rate } \\
\left(\mathrm{cm} \mathrm{yr}^{-1}\right)\end{array}$ & $\begin{array}{c}\text { Clay }(\%) \\
<2 \mu \mathrm{m}\end{array}$ & $\begin{array}{c}\text { Silt }(\%) \\
2-63 \mu \mathrm{m}\end{array}$ & $\begin{array}{c}\text { Sand }(\%) \\
63<\mu \mathrm{m}\end{array}$ & Unit \\
\hline $0-15$ & Dark reddish brown sediment & 0.42 & 27 & 27 & 46 & Ia \\
$15-48$ & $\begin{array}{c}\text { Dark gray sediment } \\
\text { plant remains and charcoal }\end{array}$ & 1.34 & 27 & 27 & 46 & Ib \\
$48-88$ & Dark gray sediment & 1.16 & 27 & 66 & 7 & Ic \\
$88-111$ & $\begin{array}{c}\text { Dark brown sediment } \\
\text { plant remains and charcoal }\end{array}$ & n.c. & 27 & 26 & 47 & II \\
\hline
\end{tabular}


Table 2

\begin{tabular}{|c|c|c|c|c|c|c|c|c|c|c|c|c|c|}
\hline \multirow[t]{2}{*}{ Unit } & \multirow{2}{*}{$\begin{array}{l}\text { Depht } \\
\text { (cm) }\end{array}$} & \multicolumn{3}{|c|}{$\mathrm{CuO}$ oxidation yield } & \multicolumn{6}{|c|}{ Organic petrography } & \multirow[b]{2}{*}{$\mathrm{Cut}+\mathrm{Mb}$} & \multirow[b]{2}{*}{$\mathrm{Ld}$} & \multirow[b]{2}{*}{ Charcoal } \\
\hline & & $\lambda$ & $\mathrm{C} / \mathrm{V}$ & $\mathrm{S} / \mathrm{V}$ & $(\mathrm{Ad} / \mathrm{Al}) \mathrm{v}$ & DHBA/V & Gel AOM & $\mathrm{Fl} \mathrm{AOM}$ & Algal OM & LC & & & \\
\hline \multirow[t]{3}{*}{ Unit Ia } & 1 & 1.39 & 0.61 & 1.23 & 0.58 & 0.26 & 36.5 & 1.0 & 2.0 & 26.4 & 32.7 & 0.8 & 0.5 \\
\hline & 11 & 0.93 & 0.66 & 1.04 & 0.23 & 0.24 & 18.3 & 12.9 & 0.0 & 54 & 12.9 & 0.0 & 1.9 \\
\hline & 14.8 & 1.24 & 0.4 & 1.07 & 0.24 & 0.18 & 12.5 & 6.5 & 1.6 & 22.4 & 50.6 & 0.0 & 6.5 \\
\hline \multirow[t]{4}{*}{ Unit Ib } & 20 & 1.6 & 0.54 & 1.08 & 0.17 & 0.22 & 20.9 & 0.5 & 0.0 & 40.4 & 32.1 & 0.0 & 6.1 \\
\hline & 23 & 2.17 & 0.31 & 0.84 & 0.34 & 0.09 & 16.3 & 8.6 & 0.0 & 42 & 30.3 & 0.0 & 2.7 \\
\hline & 31 & 3.36 & 0.42 & 1.17 & 0.07 & 0.09 & 7.3 & 0.7 & 0.0 & 19.1 & 50.9 & 0.0 & 22 \\
\hline & 40 & 3.94 & 0.27 & 1.45 & 0.05 & 0.11 & 36.3 & 3.9 & 0.0 & 37.4 & 22.4 & 0.0 & 0.0 \\
\hline \multirow[t]{8}{*}{ Unit Ic } & 44.5 & 0.68 & 0.45 & 1.11 & 0.27 & 0.0 & 18.1 & 12.2 & 0.5 & 47.4 & 21.1 & 0.0 & 0.7 \\
\hline & 51 & 0.85 & 0.39 & 1.06 & 0.43 & 0.2 & 6.4 & 12.9 & 2.6 & 63.5 & 12 & 0.9 & 1.7 \\
\hline & 58 & 1.02 & 0.32 & 1.0 & 0.6 & 0.28 & 1.9 & 33.4 & 1.56 & 43.3 & 9.7 & 0.6 & 9.5 \\
\hline & 61 & 2.18 & 0.41 & 1.14 & 0.35 & 0.24 & 1.7 & 17.6 & 0.0 & 56.1 & 22.9 & 1.7 & 0.0 \\
\hline & 68 & 0.99 & 0.18 & 0.82 & 0.5 & 0.2 & 1.6 & 23.9 & 0.0 & 57.7 & 15.5 & 1.3 & 0.0 \\
\hline & 70 & 1.55 & 0.5 & 1.09 & 0.37 & 0.22 & 5.2 & 9.0 & 4.2 & 46.7 & 30.6 & 4.3 & 0.0 \\
\hline & 78 & 0.89 & 0.17 & 0.87 & 0.47 & 0.2 & 8.2 & 5.5 & 0.0 & 47.4 & 24.6 & 6.0 & 8.3 \\
\hline & 87 & 0.71 & 0.22 & 1.1 & 0.69 & 0.32 & 7.3 & 12 & 0.0 & 49 & 27.9 & 1.5 & 2.3 \\
\hline \multirow[t]{4}{*}{ Unit II } & 90 & 2.68 & 1.59 & 1.61 & 0.33 & 0.7 & 15.2 & 8.9 & 0.0 & 57.4 & 15.8 & 1.9 & 0.7 \\
\hline & 94 & 1.12 & 0.19 & 0.7 & 0.27 & 0.34 & 7.9 & 7.5 & 0.0 & 56.5 & 26.3 & 0.9 & 0.9 \\
\hline & 100 & 0.78 & 0.49 & 1.49 & 0.2 & 0.4 & 21.5 & 2.3 & 0.0 & 30.3 & 40.4 & 1.6 & 4.0 \\
\hline & 110 & 2.91 & 0.26 & 0.99 & 0.16 & 0.18 & 32.3 & 0.2 & 0.0 & 43.1 & 24.4 & 0.0 & 0.0 \\
\hline
\end{tabular}

2 